\section{Mechanism for Unusual Accumulation of Chattonella sp. at the Southeast Region of the Inmost Part in Kagoshima Bay*1}

Short Paper
Chattonella sp. as a red tide plankton in Kagoshima Bay in 1977 showed the highest density (about $1.4 \times$ $10^{5}$ cells $/ \mathrm{ml}$ ) at the station southeast of the inmost part of the bay (st. 7) on June 14. ${ }^{1)}$ YoshiDA and NUMATA $^{2)}$ reported that this highest density would be resulted from the tidal current flowing toward the station at about 13:00 in the day. But the different current pattern was suggested through further examination by the authors. Because the lag of tidal time had actually occurred day by day although its lead had been considered in the previous paper. ${ }^{2)}$ In the present paper, the change of tidal pattern and the wind during floating time of Chattonella sp. in June 1977 were reexamined to reveal the mechanisms which caused the highest density on June 14 .

The direction and the velocity of wind and tidal current, and tidal time were referred to the data of Kagoshima Local Meteorological Observatory (1977), and the chart of tidal current in Kagoshima Bay (1979) and the tidal table (1977) which were both published by Maritime Safety Agency, all of which had been referred in the previous paper. ${ }^{2)}$

Fig. 1 shows the patterns of the current in the northern part of Kagoshima Bay. The patterns of the current at about 13:00 were c on June 11, b on 13, and a on 17. The current of the inmost part at 13:00 around June 13 didn't flow toward the southeast, as was mentioned in the previous paper (pattern e), but northward (pattern b). Therefore, it cannot explain the highest density observed at the station southeast of the inmost part (st. 7 of the previous paper ${ }^{2)}$ ).

On June 12, the tidal current of the channel began to flow into the inmost part of the bay at 12:14 (pattern b) although it flowed out in the morning (pattern $\mathbf{f}, \mathbf{a}$ ). Then, the velocity of the current increased gradually and reached maximum at 14:30 (pattern c), and the current in the inmost part rotated clockwise to eastward until 16:35 (pattern b, c, d). On June 16, seawater near the channel flowed out from the inmost part until about 14:00, and then began to flow in inversely (pattern b). The tidal current in the inmost part flowed toward the channel in the morning (pattern e, f) and then rotated clockwise to northward until 14: 47 (pattern a, b). As for the wind, a westerly (WNW) one blew at the velocity of $3-7 \mathrm{~m} / \mathrm{s}$ on June 12 , whereas a westerly one blew weakly at about $2 \mathrm{~m} / \mathrm{s}$ velocity on June 16.

A lot of Chattonella sp. had been already observed in the inmost part of Kagoshima Bay since June 9.1) Afterward, the repetition of such a clockwise rotation of tide as was observed on June 12 over a several days and the westerly strong wind blowing on June 12 would accumulate Chattonella $\mathrm{sp}$. along the eastern coast of the inmost part and, in consequence, cause the highest density in June 14. Around June 16, Chattonella sp. seemed to be transferred to the western region of the inmost part and to flow out through the channel by the westerly tidal current to decrease.

Mariko NAKAYA*2 and Yoichi YoshIDA*2

Division of Tropical Agriculture, Graduate School of Agriculture, Kyoto University, Kyoto 606, Japan.

\section{References}

1) Kagoshima Prefectural Fisheries Experimental Station: in "The Investigative Report about the Cause of Red Tide in Kagoshima Bay" (ed, by The Fisheries Agency), 1978, pp. 10-18.

2) Y. Yoshida and K. Numata: Bull. Japan Soc. Sci. Fish., 48, 1401-1405 (1982).

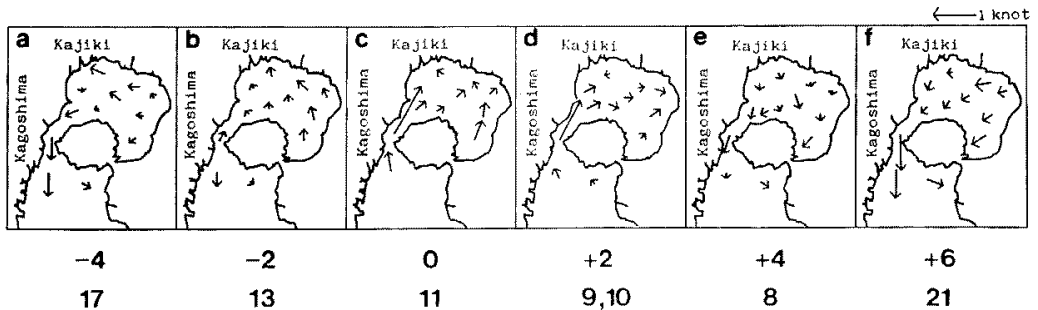

A

B

$\begin{array}{crr} & \text { Date } & \\ & \\ \text { June } 12 & 10: 09 \\ & 13 & 10: 51 \\ 14 & 11: 28 \\ 15 & 12: 06 \\ 16 & 12: 42\end{array}$

12:14

$12: 56$

13:33

14:11

$14: 47$
Time

$\begin{array}{rrrr}14: 30 & 16: 35 & & 8: 04 \\ 15: 15 & 17: 20 & & 8: 46 \\ 15: 53 & 17: 58 & & 9: 23 \\ 16: 29 & & 7: 35 & 10: 01 \\ 17: 03 & & 8: 12 & 10: 37\end{array}$

Fig. 1. Patterns of the main current (about $5 \mathrm{~m}$-depth) in the northern part of Kagoshima Bay in 1977. A; elapsed time (h) from when the northern stream through the channel is strongest, $B$; date when the current pattern occurred at about 13:00 in June, C; time when the pattern occurred during floating time of Chattonella on each day.

\footnotetext{
(Accepted November 11, 1983)

*1 鹿児泉湾奥東南部における Chattonella sp.の異常集積の機構.

*2 中谷亡り子・吉田陽一: 京都大学大学院農学研究科熱带農学尃攻, 京都市。
} 